\title{
The Relationship between Intended Learning Outcomes and Student Assessment in Courses of Social Work with Individuals and Families
}

Hesham S. Abdelmaguid (PhD)

Faculty of Social Work- Helwan University

Mona A. Abdel Mawgoud

Faculty of Social Work- Helwan University

Abstract:

This paper is designed to determine the correlation between the intended learning outcomes and the method of student assessment in courses of social work with individuals and families within the BA program of social work at the Faculty of Social Work at Helwan University. This article contributes towards helping faculties with the process of constructing intended learning outcomes and methods for assessing those outcomes in their programs and courses. A sample size of 90 students ( 70 female, 20 male), at grade three of the BA program, was selected to respond to the study questionnaire. The results indicated a statistically significant correlation between the intended learning outcomes for the courses of social work with individuals and families and the method of student assessment in these courses. In addition, the results indicated the presence of deficiencies in curriculum contents and teaching methods in terms of their diversity and ability to achieve the intended learning outcomes.

Keywords: Intended Learning Outcomes - Assessment - social work with individuals and families

\section{Introduction:}

Social work education has always contained both academic and practical components. Social work education comprises of a theoretical component taught in the classroom, and field-based education involving integration of the academic aspect and practice (Dhemba, 2012, p. 1).

A career in social work requires many abilities. Social workers must have competence in relating to individuals, families, small groups, organizations, and communities; in assessing needs and problems; and in planning and intervening appropriately. Social workers have to be skilled in carrying out various helping roles such as advocate, broker, educator, group leader, mediator, clinician, community planner and organizer, administrator, and so forth (Garthwait, 2014, p.3) 
Abu Almaati (2005) identified a number of problems that have negatively influenced social work education in Egypt, such as the use of old methods of teaching that rely solely on lecturing; lack of coordination between schools of social work and the job market; and the over-dependency on western models of social work education. Due to increasing pressure from society to adopt new strategies and provide high-quality education, social work educators have started to discuss how to revise social work education in Egypt (Mokhtar, 2006). A number of initiatives have been prepared to address these issues, focusing on: first, the interests of faculty members and their receptivity to change; second, the structure of social work programs and the degree to which they can be flexible; third, the contribution of social work to society (Soliman, \& Abdelmaguid 2010).

Working at the micro level is one of the most important forms of social work, which involves dealing with the individuals and families problems through social counselling and clinical social work. Therefore, social work education programs aim to provide students with basic intervention skills during the bachelor's degree through a series of courses. These courses include an introduction to generalist social work with individuals and families, practice foundations of social work with individuals and families, and practice processes in social work with individuals and families, in addition to field training.

However, many previous studies have shown many shortcomings in the application of problem solving skills by graduates of social service schools at the bachelor level, when dealing with individuals and families. The results of a Helmi (2000) study found that there are shortcomings in dealing with family problems that need to provide more modern and effective models of practice. Kasem (2006) also indicated in the results of his study that there are many shortcomings in the practice of social workers in solving problems for school students. These shortcomings include a lack of awareness among social workers of the nature of school students' problems, the inability of social workers to assess students' problems and propose a plan to deal with them, in addition to the difficulties of using professional intervention techniques and strategies to deal with these problems.

This means that programs and courses of social work, especially in the field of social work with individuals and families, need to be developed commensurate with the needs of the labour 
market and in light of recent global developments in the areas of specialization. The Faculty of Social Work at Helwan University developed its own curriculum and courses, including courses for working with individuals and families. This development includes guidance on national academic standards, objectives and learning outcomes for each course, as well as assessment and examination methods for students to verify the extent to which these results are achieved.

In order to ensure the effectiveness of these courses in developing students' knowledge and professional intervention skills with individuals and families, it is necessary to identify the intended learning outcomes. These must be based on academic standards and must reflect the knowledge and range of skills that students need to develop during the bachelor's degree. It is also necessary to identify accurate and varied ways for measuring the extent to which students develop their knowledge and skills during their studies.

Intended learning outcomes are not only a way of quality assuring applications at associations of higher education, but also represent the translation of the teacher's design aims into specific, tangible, attainable learning achievements for students, usually expressed as observable demonstrations of what students know, are able to do, or are able to accomplish. Learning outcomes are those specific outcomes which are observable through students' performances and which constitute the basis on which assessments are made of students' achievements.

\section{Intended Learning Outcomes (ILOs):}

The ILOs are statements, written from the student's perspective, indicating the level of understanding and performance they are expected to achieve as a result of engaging in the teaching and learning experience. The ILOs of the nature of teaching and learning were, in order of cognitive level, with the learning activities or verbs italicized (Biggs \& Tang 2007, p. 55):

1) Explain in depth why a particular course topic is important to teaching.

2) Explain how the component course topics interrelate.

3) Reflect on your teaching in terms of a working theory you have gained from the course.

4) Evaluate a situation that has gone wrong and apply a solution. 
Alternatively, an expected learning outcome is a formal statement of what students are expected to learn in a course. Expected learning outcome statements refer to specific knowledge, practical skills, areas of professional development, attitudes, higher-order thinking skills, etc. that faculty members expect students to develop, learn, or master during a course. Expected learning outcomes are also often referred to as "learning outcomes", "student learning outcomes", or "learning outcome statements" (Office of Planning and Assessment, 2008, p. 5).

A statement of learning outcome clarifies intention, but is squarely focused on the learner. It is performance-oriented, typically beginning with an action verb (e.g. 'demonstrate', 'apply'), typically written in the future tense, typically relating the action to the unit content, and typically specifying the desired level of performance. A learning outcome should be a clear statement of what the learner is expected to achieve and how he/she is expected to demonstrate that achievement. (Learning and Teaching Center, 2009, p. 1)

Writing learning outcomes for courses should not be seen as an aim in itself, they should be used as an integral part of both curriculum design and teaching. Biggs (1999) called this integration of outcomes with both assessment and teaching 'constructive alignment'. Constructive alignment means asking yourself three main questions when thinking about designing courses: (Williamson, 2013, p.16)

- What should the students know or be able to do by the end of the course (what are the intended learning outcomes)?

- What methods will I use in my teaching to encourage students to work towards the achievement of these outcomes?

- How will I design assessment in such a way that the tasks and criteria I use help both me and the students know that they have achieved the outcomes I have intended?

\section{Taxonomies of Intended Learning Outcomes:}

A taxonomy is an orderly classification of a field of study (e.g., psychology, sociology, anthropology, etc.) according to the natural relationships within the field. Taxonomies allow different researchers to study and discuss the same field of study using shared terminology. There are many important taxonomies in the education and learning processes across the three learning domains. These taxonomies should provide a helping hand in the development of solid learning objectives and outcomes. There are three primary learning domains: 
1) Cognitive; Learning related to knowledge (i.e., from simple recognition and memory to complex problem solving and evaluation) 2) Psychomotor; Learning related to actions and motor skills (i.e., from simple actions to complex actions)

3) Affective; Learning related to attitudes, feelings, \& emotions.

There are many attempts to classify intended learning outcomes in taxonomies. The first taxonomy is that of Robert Gagné; Gagné's learning taxonomy specified the three primary domains recognized today: KSA (cognitive, psychomotor, and affective) (Thomas Ken, 2004, p.3). Elizabeth Simpson's (1966) taxonomy is focused on the progression of a skill from guided response (i.e., doing what you are told to do) to reflex or habitual response (i.e., not having to think about what you're doing), then includes origination as the highest level (i.e., invention of a new way to perform a task) (Thomas, 2004, p.10).

Authors of this article preferred to choose Bloom's Taxonomy for many reasons, including:

1) The Bloom model is the most popular and simple model for formulating intended learning outcomes for educational programs.

2) Intended learning outcomes for the National Authority for Quality Assurance and Accreditation in Egypt were formulated based on the Bloom model.

3) This model was revised and changed by Anderson and Krathwohl Taxonomy, as you see below.

\section{Bloom's Taxonomy:}

In 1956, Benjamin Bloom along with a group of like-minded educators developed a framework for classifying educational goals and objectives into a hierarchical structure representing different forms and levels of learning. This framework was published as Bloom's Taxonomy of Educational Objectives and consisted of the following three domains: (IACPE, 2016, p.1)

1) The Cognitive Domain - knowledge-based domain, consisting of six levels, encompassing intellectual or thinking skills.

2) The Affective Domain - attitudinal-based domain, consisting of five levels, encompassing attitudes and values.

3) The Psychomotor Domain - skills-based domain, consisting of six levels, encompassing physical skills or the performance of actions. 
Bloom's original 1956 Taxonomy of Educational Objectives identified the following levels of cognitive learning (arranged from lower-order to higher-order levels of learning) (IACPE, p.1):

1) Knowledge - The remembering of previously learned material; this involves the recall of a wide range of material, from specific facts to complete theories.

2) Comprehension - The ability to grasp the meaning of previously learned material; this may be demonstrated by translating material from one form to another, interpreting material (explaining or summarizing), or by predicting consequences or effects.

3) Application - The ability to use learned material in new and concrete situations; this may include the application of rules, methods, concepts, principles, laws, and theories.

4) Analysis - The ability to break down material into its component parts, so that its organizational structure may be understood; this may include the identification of the parts, analysis of the relationships between parts, and recognition of the organizational principles Synthesis - The ability to put parts together to form a new whole; this may involve the production of a unique communication (thesis or speech), a plan of operations (research proposal), or a set of abstract relations (scheme for classifying information).

5) Evaluation - The ability to judge the value of material for a given purpose; the judgments are to be based on definite internal and/or external criteria.

Anderson and Krathwohl revised Bloom's taxonomy to change the category names from nouns to verbs, and to switch the Evaluation and Synthesis levels in the hierarchy (Anderson \& Krathwohl, 2001).

Table (5): Revised Anderson and Krathwohl version of Bloom's Taxonomy

\begin{tabular}{|l|l|}
\hline Category & Description \\
\hline Remember & Ability to recall previously learned material. \\
\hline Understand & Ability to grasp meaning, explain, restate ideas. \\
\hline Apply & Ability to use learned material in new situations. \\
\hline Analyse & $\begin{array}{l}\text { Ability to separate material into component parts and show } \\
\text { relationships between parts. }\end{array}$ \\
\hline Evaluate & Ability to judge the worth of material against stated criteria. \\
\hline Create & $\begin{array}{l}\text { Ability to put together separate ideas to form completely new } \\
\text { ideas and establish new relationships. }\end{array}$ \\
\hline
\end{tabular}


The National Authority for Quality Assurance and Accreditation of Education in Egypt (NAQAAE) revised Bloom's taxonomy and compacted it into four levels:

1) Knowledge and Understanding: Knowledge is the intended information to be gained from an educational activity including facts, terms, theories and basic concepts. Understanding involves comprehending and grasping the meaning or the underlying explanation of scientific objects.

2) Intellectual Skills: Learning and cognitive capabilities that involve critical thinking and creativity. These include application, analysis, synthesis and evaluation of information.

3) Professional and Practical Skills: Application of specialized knowledge, training and proficiency in a subject or field to attain successful career development and personal advancement.

4) General and Transferable Skills: Skills that are not subjectspecific and commonly needed in education, employment, lifelong learning and self-development. These skills include communication, teamwork, numeracy, independent learning, interpersonal relationship, and problem solving... etc.

Finally, the intended learning outcomes can be defined operationally in this study as the set of knowledge, mental skills, practical skills and general skills that are expected to be acquired by the bachelor students of Social Work in the courses of work with individuals and families.

\section{What is Educational assessment?}

Educational assessment has traditionally meant the assessment of educational achievement; how well pupils master the knowledge, skills, and contents taught according to the curriculum and required as end results of, or entry requirements for, diverse levels of education. (Jarkko et al 2002, p. 9)

According to Palomba and Banta (1999), assessment involves the systematic collection, review, and use of evidence or information related to student learning. Assessment helps a faculty identify how well their students understand course topics/lessons. Assessment exercises are often anonymous. This anonymity allows students to respond freely, rather than trying to get the "right" answer or "look good". Assessment exercises attempt to gauge students' understanding in order to see what areas need to be re-addressed to improve students' learning. (Office of Planning and Assessment, 2008, p. 12) 
In other words, assessment is the process of investigating (1) what students are learning and (2) how well they are learning it in relation to the stated expected learning outcomes for the course. This process also involves providing feedback to the students about their learning and providing new learning opportunities/strategies to increase student learning. (p. 12)

\section{Kinds of assessment:}

Assessment is often described in terms of formative assessment or summative assessment.

\section{Formative assessment:}

Formative assessment has been described as being assessment for learning. It has been described as assessment that "refers to all those activities undertaken by teachers, and by the students in assessing themselves, which provide information to be used as feedback to modify the teaching and learning activities in which they are engaged" (Black and Williams, 1998). In other words, formative assessment helps to inform the teacher and the students as to how the students are progressing. Formative assessment is usually carried out at the beginning of a programme or during a programme. The students' performance on the assessment tasks can help the teacher to make decisions about the direction of the teaching to help the learning process. It has been clearly shown (Black \& Williams, 1998) that by giving feedback to learners, formative assessment can help improve the learning and performance of students. The main characteristics of formative assessment include (Kennedy, D, 2007, p. 62):

- Identification by teachers and students of the learning outcomes and the criteria for achieving these.

- The provision of clear and rich feedback in an effective and timely fashion.

- The active involvement of students in their own learning.

- Good communication between teacher and students.

- The response by the teacher to the needs of the students.

\section{Summative assessment:}

A summative assessment is an assessment, which aims to summarize student learning at a particular point in time - usually at the end of a module or programme. Summative assessment has been described as "end-of-course assessment and essentially means that this is assessment which produces a measure which sums up someone's 
achievement and which has no other real use except as a description of what has been achieved" (Kennedy, 2007, p.63)

Thus, the use of summative assessment enables a grade to be generated that reflects the student's performance. Unfortunately, summative assessment is often restricted to just the traditional examination paper and does not involve other areas such as project work, portfolios or essays. Because of the nature of summative assessment, not all learning outcomes can be assessed at any one time. Assessment of just a sample of learning outcomes is common.

\section{Methods for Assessing Learning Outcomes:}

Formal Assessment Activities for Assessing Expected Learning Outcomes: Exams- Homework Assignments- Quizzes- In-Class Activities- Papers- Class Discussion.

Informal Assessment Activities for Assessing Expected Learning Outcomes: Non-Graded Quizzes- Active Learning Techniques"Muddiest Point" Activities- Polling the class- One Minute PapersApplication Cards- Reaction Papers.

What is involved in the assessment process?

1. Establishing expected learning outcomes for the course;

2. Systematically gathering, analysing, and interpreting evidence (through formal assessment activities such as exams or papers and informal assessment activities such as in-class discussions or "muddiest point" exercises) to determine how well the students' learning matches:

a) Faculty expectations for what students will learn

b) The stated expected learning outcomes for the course

3. Faculty members should use this evidence/assessment of student learning to: (Office of Planning and Assessment, 2008, p. 12)

a) Provide feedback to students about their learning (or lack thereof).

b) Adjust their teaching methods and/or students' learning behaviours to ensure greater student learning.

Linking Learning Outcomes, Teaching and Learning Activities and Assessment:

1) Identify aims and objectives of the course or programme.

2) Clearly define the learning outcomes.

3) Select teaching and learning methods that are likely to ensure that the learning outcomes are achieved. 
4) Choose a technique or techniques to assess the achievement of the learning outcomes.

5) Assess the learning outcomes and check to see how well they match with what was intended.

\section{Assessment of ILOs:}

There are a range of assessment processes conducted by higher education institutions that measure the achievement of all intended learning outcomes, specifically appropriate levels of knowledge, intellectual and professional skills. Assessments also provide the means by which students are ranked according to their achievement.

This study attempted to determine the evaluation of bachelor's degree students studying at the Faculty of Social Work at Helwan University in Egypt, the extent of commitment to the intended learning outcomes for the courses of intervention with individuals and families, as well as the methods of student assessment and the extent to which these related to intended learning outcomes. Therefore, this study is aimed at identifying the relationship between the intended learning outcomes and the methods of evaluation and examinations used with students, considering the differences between students in terms of gender as well as their level of achievement (high - medium weak) reflected by different test results.

A number of hypotheses were articulated based on a review of available literature on intended learning outcomes and assessment of student achievement, and the course descriptions; these courses formed the foundations of social work with individuals and families, and the processes of practice with individuals and families. These hypotheses included:

1) There is a statistically significant correlation between students' responses in the dimension of intended learning outcomes and their responses in the dimension of student achievement assessment in the courses of social work with individuals and families.

2) There is a statistically significant inverse correlation between the degree of success in the final grade of the students (highmedium- weak) and their responses on the dimension of intended learning outcomes.

3) There is a statistically significant correlation between the degree of success in the final grade of the students (high- 
medium- weak) and their responses on the dimension of student achievement assessment.

4) There is a statistically significant difference between the mean female score and the mean male score on the total number of scores and sub-dimensions of the questionnaire.

\section{Methodology: \\ Sample:}

The population of the study consists of social work students at grade three from the Faculty of Social Work at Helwan University in Egypt. A stratified random sample of 90 students (15\%) was selected from 600 students, 466 (Female) and 132 (Male), who attended the summer training camp. Students were invited to voluntarily participate in the study, and were given an oral explanation of the study goals and procedures, and assurance of the confidentiality of identity and information provided. The study author asked for students' approval to participate in data collections, all but three students approved.

Descriptive analyses of the study sample show that 20 of the participants are male (22.2\%) and 70 are female $(77.8 \%)$. The distribution of the participants by the results of their final exam is 44 (48.9\%) high-level score (excellent \& very good), $24(26.7 \%)$ medium-level score (good), and 22 (24.4\%) low-level score (pass).

\section{Procedure:}

This study was approved by the faculty of Social Work at Helwan University. The research instruments and demographic information sheet were provided to students who gave oral consent to participate in this research activity during their admission interview, except for three students. Information was collected from participants who were divided into four groups; three female groups (each group having 23 participants) and one male group (of 20 participants). The data were collected through group sessions. At the start of each session, the authors explained the questionnaire for each group and gave participants guidance for completing it. Statistical program Spss was used to analyse the data collected in order to attain the results of the research, such as the correlation coefficient, T.Test and Spearman Brown equation.

\section{Instrument:}

A questionnaire, based on the available contents and course description of social work with individuals and families, and national reference standards of social work education (NARS), was designed 
by the authors. The questionnaire consisted of two parts; the first part contained basic information, while the second part contained two subscales, defined as follows:

1) Basic information: for example, student gender (male-female), degree of success at final grade: high level (excellent and very good), medium level (good) and low level (pass), teaching and learning tools, assessment tools.

2) Subscale (1) 'intended learning outcomes' contains 12 items. Examples of these items:

a. "The instructor explains the objectives of the course at the beginning of the semester",

b. "The instructor explains the course outcomes for knowledge and concepts",

c. "The instructor demonstrates the outcomes of the course for professional and practical skills",

d. "The contents of the course cover the objectives specified in the description",

e. "The teaching methods used in the course help to achieve the intended learning outcomes".

3) Subscale (2) 'student assessment' contains 9 items. Examples of these items:

a. "Methods of student assessment in the course are announced and clearly defined in the course description",

b. "The course instructor is committed to the assessment times specified in the description",

c. "Assessment methods and exams vary throughout the semester",

d. "The course instructor announces the results of the examinations after correcting them.",

e. "The course instructor discusses the results of the examinations with the students after they are corrected".

\section{Validity:}

The process of assessing the validity of the questionnaire included construct validity and internal consistency of the subscales and items. In terms of construct validity, the questionnaire has drawn its concepts from the education literature on curriculum development and the relevancy of the courses of social work with individuals and families. Based on the literature on quality assurance and national academic references standards manual, a number of concepts were discussed, including the intended learning outcomes, students' 
academic assessment, learning and teaching tools, and academic assessment tools.

In terms of internal consistency, after applying the questionnaire to the sample of 90 students (male and female), the authors calculated the correlation coefficient between: (1) the scores of each questionnaire item and the total number of questionnaire scores, (2) the total scores of each dimension of the questionnaire and the total number of test scores as shown in the following tables:

Table (1): The correlation coefficient between the scores of each questionnaire item and the total number of questionnaire scores

\begin{tabular}{|l|l|l|l|l|l|}
\hline Item & correlation & Item & correlation & Item & correlation \\
\hline 1 & $0.731^{* *}$ & 9 & $0.665^{* *}$ & 17 & $0.656^{* *}$ \\
\hline 2 & $0.664^{* *}$ & 10 & $0.763^{* *}$ & 18 & $0.743^{* *}$ \\
\hline 3 & $0.683^{* *}$ & 11 & 0.442 & 19 & $0.694 * *$ \\
\hline 4 & $0.692^{* *}$ & 12 & $0.764^{* *}$ & 20 & $0.780^{* *}$ \\
\hline 5 & $0.654^{* *}$ & 13 & $0.686^{* *}$ & 21 & $0.777^{* *}$ \\
\hline 6 & 0.423 & 14 & $0.672^{* *}$ & 22 & $0.628 * *$ \\
\hline 7 & $0.673^{* *}$ & 15 & $0.767 * *$ & 23 & $0.784 * *$ \\
\hline 8 & $0.732^{* *}$ & 16 & 0.382 & 24 & $0.754 * *$ \\
\hline
\end{tabular}

Table (1) shows a statistically significant correlation between the scores of each questionnaire item and the total number of its scores at the level of significance of 0.01 .

Table (2): The correlation coefficient between the total scores of each dimension of the questionnaire and the total number of questionnaire scores.

\begin{tabular}{|l|l|l|}
\hline Dimension & Correlation coefficient & Significance level \\
\hline Intended learning outcomes & $0.718^{* *}$ & 0.01 \\
\hline Assessment & $0.774^{* *}$ & 0.01 \\
\hline
\end{tabular}

Table (2) shows a statistically significant correlation between the scores of each dimension of the questionnaire and the total number of its scores at the level of significance of 0.01 . This indicates that there is an appropriate degree of validity of the questionnaire.

\section{Reliability:}

The authors calculated the coefficient of the questionnaire reliability between the two halves of each dimension as shown in Table (3), as well as the calculation of the reliability coefficient between the two dimensions of the questionnaire as a whole by the use of split-half. The reliability of the subscales ranged from .79 to .81 with an overall reliability coefficiency of the entire scale at .76 . 
Table (3) the reliability of the questionnaire using the split-half through the Spearman Brown equation

\begin{tabular}{|l|l|l|}
\hline Dimensions & Number of items & Reliability \\
\hline Intended learning outcomes & 12 & $0.79^{* *}$ \\
\hline Assessment & 9 & $0.81^{* *}$ \\
\hline Total number of questionnaire items & 21 & $076^{* *}$ \\
\hline
\end{tabular}

\section{Results:}

The results indicated that most of the methods of educating and teaching used in the courses of social work with individuals and families are lecture $100 \%$, group discussion $65 \%$ workshop $30 \%$, and practical training $2 \%$.

On the other hand, the most common types of tests in the assessment of students in the courses are written examinations $100 \%$, oral examinations 84\%, file completion (portfolio) $70 \%$, cases analysis $68 \%$, and finally applied projects $28 \%$. The most common student assessment methods used are short essay questions $100 \%$, multiple choice $85 \%$, right and wrong questions $83 \%$, and finally long essay questions $30 \%$.

As shown in table (4) the results of study indicated the following:

Table (4) Correlation coefficients between students' scores in both the intended learning outcomes (ILOs) and the academic assessments of the students according to their degree of success at the final grade.

\begin{tabular}{|l|l|l|l|}
\hline Dimension & degree of success & I.LOs. & assessment \\
\hline degree of success & 1.000 & $-0.282^{* *}$ & -0.162 \\
\hline I.LOs. & $-0.282^{* *}$ & 1.000 & $0.630^{* *}$ \\
\hline assessment & -0.162 & $0.630^{* *}$ & 1.000 \\
\hline
\end{tabular}

As shown in table (4) there is a statistically significant correlation between the students' scores in the intended learning outcomes dimension of the courses and their scores in the dimension of student achievement assessment. Where the correlation coefficient was 0.630 at a significant level of 0.01 . This generally indicates a degree of consistency in students' views between the intended learning outcomes of these courses and assessment methods used to assess their academic achievement. This result supports the validity of the first study hypothesis. The results also indicate a statistically significant inverse correlation between the degree of success in the final grade of the students and their scores in the intended learning outcomes (ILOs), where the correlation coefficient was -0.282 , at a significant level of 0.01 . This indicates that the higher the success rate 
of students in the courses, the lower their ratings of the intended learning outcomes. This result supports the validity of the second study hypothesis. Finally, there was a non-statistically significant inverse correlation between degree of success in the final grade of the students and their methods of assessment in the courses where the correlation coefficient was 0.162 . This indicates that there is no clear discrepancy between students according to the degree of success in their assessments in these courses. This result did not validate the third study hypothesis.

The results of hypothesis No. 4 are shown in table (5) as follows:

Table (5) Significant differences between the mean of the male scores and the mean of the female scores on the intended learning outcomes, students' assessment and total scores in the questionnaire

\begin{tabular}{|l|l|l|l|l|l|l|}
\hline \multirow{2}{*}{ Dimensions } & \multicolumn{2}{|l|}{ Mean } & \multicolumn{2}{l|}{ Standard Deviation } & T.Test & \multicolumn{2}{l|}{ Sig. } \\
\cline { 2 - 5 } & Male & Female & Male & Female & & 0.01 \\
\hline I.LOs & 39.8 & 40.4 & 7.6 & 8.4 & 0.294 & 0.769 \\
\hline $\begin{array}{l}\text { Student's } \\
\text { assessment }\end{array}$ & 25.1 & 27.1 & 6.6 & 5.6 & 1.352 & 0.180 \\
\hline Total Sores & 64.9 & 67.5 & 13.0 & 12.9 & 0.797 & 0.428 \\
\hline
\end{tabular}

The results as shown in Table (5) showed no statistically significant differences between the male mean scores and female mean scores in the total number of scores and the sub-dimensions (Intended Learning outcomes and the student assessment) where the values of " $\mathrm{T}$ " were not valid. This indicates that there is consistency between the views of students according their gender on the intended educational outcomes and methods of student assessment.

\section{Discussion:}

The results generally indicated that there was a statistically significant correlation between the intended learning outcomes for the courses of social work with individuals and families and the methods of students' assessment in these courses. This confirms the agreement of students at different levels that there is a consistency between the intended learning outcomes and the students' assessment in these courses. These results are consistent with the results of the study of Abdul Aziz Mokhtar (2005) which showed that due to increasing pressure from society to adopt new strategies and provide high-quality education, social work educators have started to discuss how to revise social work education in Egypt. It also agreed with the results of the study of Soliman H and Abdelmaguid H, (2010) that a number of 
initiatives have been prepared to address the issues of social work education in Egypt, focusing on the structure of social work programs and the degree to which they can be flexible. These initiatives can be translated through the description of these courses, for the intended learning outcomes for each course, methods of student assessment, and the compatibility between them through the matrix of each course, as shown in the following examples:

Course Title: Introduction to generalist social work with individuals and families

Course Code: CW.211- Second Year

Learning outcomes written by:

On successful completion of this course, students should be able to:

\begin{tabular}{|c|c|c|}
\hline Level of ILOs & ILOs & Assessment tools \\
\hline $\begin{array}{l}\text { Knowledge } \\
\text { (Level 1) }\end{array}$ & $\begin{array}{l}\text { - Explain generalist practice theory that } \\
\text { explains the relationship between human } \\
\text { behaviour and social environment. } \\
\text { - Determine the code of ethics that social } \\
\text { work practice is based on. }\end{array}$ & $\begin{array}{l}\text { Oral exam. } \\
\text { Written exam. }\end{array}$ \\
\hline $\begin{array}{l}\text { Intellectual } \\
\text { Skills (Level 2) }\end{array}$ & $\begin{array}{l}\text { - Differentiate between generalist practice } \\
\text { and traditional practice of social work. } \\
\text { - Analyse the basic elements of clients' } \\
\text { systems in social work. }\end{array}$ & $\begin{array}{l}\text { Research paper. } \\
\text { Homework } \\
\text { assignment. }\end{array}$ \\
\hline $\begin{array}{l}\text { Professional } \\
\text { and practical } \\
\text { Skills (Level3) }\end{array}$ & $\begin{array}{l}\text { - Apply professional roles that are } \\
\text { consistent with clients' systems problems. } \\
\text { Commit to professional values and ethics } \\
\text { related with justice and non- } \\
\text { discrimination. }\end{array}$ & $\begin{array}{l}\text { Case analysis. } \\
\text { Practical project at } \\
\text { field practice. }\end{array}$ \\
\hline $\begin{array}{l}\text { General and } \\
\text { transferable } \\
\text { skills (Level 4) }\end{array}$ & $\begin{array}{l}\text { - Conduct the conversations and other } \\
\text { activities in the class. } \\
\text { - Use information technology tools to attain } \\
\text { knowledge and experience related to } \\
\text { course content. }\end{array}$ & $\begin{array}{l}\text { Research paper written } \\
\text { observation by teacher. } \\
\text { Evaluation of students' } \\
\text { commitments in class. }\end{array}$ \\
\hline
\end{tabular}

\section{Course matrix (ILOs and Assessment):}

\begin{tabular}{|c|c|c|c|c|c|c|c|c|c|c|c|c|}
\hline \multirow{2}{*}{ Ass. tools } & \multicolumn{3}{|c|}{ knowledge } & \multicolumn{2}{c|}{ intellectual } & \multicolumn{3}{c|}{ professional } & \multicolumn{3}{c|}{ General } \\
\cline { 2 - 13 } & K1 & K2 & K3 & I1 & I2 & I3 & P1 & P2 & P3 & G1 & G2 & G3 \\
\hline Written & & & & & & & & & & & & \\
\hline Oral & & & & & & & & & & & & \\
\hline Case analysis & & & & & & & & & & & & \\
\hline project & & & & & & & & & & & & \\
\hline paper & & & & & & & & & & & & \\
\hline observation & & & & & & & & & & & & \\
\hline
\end{tabular}


Course Title: Practice foundations of social work with individuals and families

\section{Course Code: CW.221- Second Year}

On successful completion of this course, students should be able to:

\begin{tabular}{|c|c|c|}
\hline Level of ILOs & ILOs & Assessment tools \\
\hline $\begin{array}{l}\text { Knowledge } \\
\text { (Level 1) }\end{array}$ & $\begin{array}{l}\text { Explain scientific foundations of } \\
\text { social work intervention with } \\
\text { individuals and families } \\
\text { - } \quad \begin{array}{l}\text { Determine the steps of intervention } \\
\text { with individuals and families. }\end{array}\end{array}$ & $\begin{array}{l}\text { Oral exam. } \\
\text { Written exam. }\end{array}$ \\
\hline $\begin{array}{l}\text { Intellectual } \\
\text { Skills (Level } \\
\text { 2) }\end{array}$ & $\begin{array}{l}\text { - Analyse the problems of individuals } \\
\text { and families in the light of scientific } \\
\text { theories of professional intervention. } \\
\text { Connect social and psychological } \\
\text { factors to the problems of } \\
\text { individuals and families. }\end{array}$ & $\begin{array}{l}\text { Research paper. } \\
\text { Homework assignment. }\end{array}$ \\
\hline $\begin{array}{l}\text { Professional } \\
\text { and practical } \\
\text { Skills (Level3) }\end{array}$ & $\begin{array}{l}\text { Design the intervention plan with } \\
\text { individuals and families. } \\
\text { - Use methods to identify problems of } \\
\text { individuals and families. }\end{array}$ & $\begin{array}{l}\text { Case analysis. } \\
\text { Workshops. } \\
\text { Case analysis. }\end{array}$ \\
\hline $\begin{array}{l}\text { General and } \\
\text { transferable } \\
\text { skills (Level } \\
\text { 4) }\end{array}$ & $\begin{array}{l}\text { - Conduct the conversations and other } \\
\text { activities in the class. } \\
\text { - Use information technology tools to } \\
\text { attain knowledge and experience } \\
\text { related to course content. }\end{array}$ & $\begin{array}{l}\text { Research paper written } \\
\text { observation by teacher. } \\
\text { Evaluation of students' } \\
\text { commitment in class. }\end{array}$ \\
\hline
\end{tabular}

\section{Course matrix (ILOs and Assessment):}

\begin{tabular}{|l|l|l|l|l|l|l|l|l|l|l|}
\hline \multirow{2}{*}{ Ass. tools } & \multicolumn{3}{l}{ knowledge } & \multicolumn{2}{l}{ intellectual } & \multicolumn{2}{l|}{ professional } & Gener: \\
\cline { 2 - 12 } & K1 & K2 & K3 & I1 & I2 & I3 & P1 & P2 & P3 & G1 \\
\hline Written & & & & & & & & & & \\
\hline Oral & & & & & & & & & & \\
\hline Case analysis & & & & & & & & & & \\
\hline workshops & & & & & & & & & & \\
\hline paper & & & & & & & & & & \\
\hline observation & & & & & & & & & & \\
\hline
\end{tabular}

Course Title: Practice processes in social work with individuals and families

Course Code: CW.321- third Year

Learning outcomes written by

On successful completion of this course, students should be able to:

\begin{tabular}{|l|l|l|}
\hline Level of ILOs & ILOs & Assessment tools \\
\hline $\begin{array}{l}\text { Knowledge } \\
\text { (Level 1) }\end{array}$ & $\begin{array}{l}\text { Determine the problems of } \\
\text { individuals and families in different } \\
\text { practice fields. }\end{array}$ & $\begin{array}{l}\text { Oral exam. } \\
\text { Written exam. }\end{array}$ \\
\hline
\end{tabular}




\begin{tabular}{|c|c|c|}
\hline & $\begin{array}{l}\text { - Describe the steps of intervention } \\
\text { into the problems of individuals and } \\
\text { families according to the nature of } \\
\text { these problems. }\end{array}$ & \\
\hline $\begin{array}{l}\text { Intellectual Skills } \\
\text { (Level 2) }\end{array}$ & $\begin{array}{l}\text { - Analyse the data and information } \\
\text { related to the problems that he or she } \\
\text { deals with according to their nature. } \\
\text { Explain the causes of the problems } \\
\text { experienced by individuals and } \\
\text { families according to the nature of } \\
\text { these problems and the clients. }\end{array}$ & $\begin{array}{l}\text { Research paper. } \\
\text { Homework assignment. }\end{array}$ \\
\hline $\begin{array}{l}\text { Professional } \\
\text { and practical } \\
\text { Skills (Level3) }\end{array}$ & $\begin{array}{l}\text { - Hold interviews with individuals and } \\
\text { families in light of specific } \\
\text { problems. } \\
\text { Plan his/her professional roles } \\
\text { according to the specific problems } \\
\text { of individuals and families. }\end{array}$ & $\begin{array}{l}\text { Case analysis. } \\
\text { Workshops. } \\
\text { Homework. }\end{array}$ \\
\hline $\begin{array}{l}\text { General and } \\
\text { transferable skills } \\
\text { (Level 4) }\end{array}$ & $\begin{array}{l}\text { - Use communication skills with } \\
\text { clients according to the nature of } \\
\text { their problems. } \\
\text { - Conduct dialogues with staff in an } \\
\text { appropriate manner. }\end{array}$ & $\begin{array}{l}\text { Research paper written } \\
\text { observation by teacher. } \\
\text { Evaluation of students' } \\
\text { commitment in class }\end{array}$ \\
\hline
\end{tabular}

\section{Course matrix (ILOs and Assessment):}

\begin{tabular}{|l|l|l|l|l|l|l|l|l|l|l|l|l|}
\hline \multirow{2}{*}{ Ass. tools } & \multicolumn{2}{|l|}{ knowledge } & \multicolumn{2}{l|}{ intellectual } & \multicolumn{3}{l|}{ professional } & \multicolumn{3}{|l|}{ General } \\
\cline { 2 - 13 } & K1 & K2 & K3 & I1 & I2 & I3 & P1 & P2 & P3 & G1 & G2 & G3 \\
\hline Written & & & & & & & & & & & & \\
\hline Oral & & & & & & & & & & & & \\
\hline $\begin{array}{l}\text { Case } \\
\text { analysis }\end{array}$ & & & & & & & & & & & & \\
\hline workshops & & & & & & & & & & & & \\
\hline paper & & & & & & & & & & & & \\
\hline observation & & & & & & & & & & & & \\
\hline
\end{tabular}

The results also showed a statistically significant inverse relation between the degree of success of students in the previous school year and their scores in the dimension of intended learning outcomes. This means that students with a high level of success (excellent - very good) had lower scores for intended learning outcomes than students with lower and middle school levels. This indicates that students with a higher level of success are more accurate in evaluating the intended learning outcomes. This has been reflected in their responses to some of the questionnaire items that have obtained fewer grades such as "The course contents achieves practical 
skills", "The methods used to teach the course are diverse", and "Teaching methods helps to achieve intended learning outcomes". This means that there are deficiencies in some curriculum contents, as well as teaching methods, in terms of their diversity and their ability to achieve intended learning outcomes. The results also indicated that the most common teaching methods used in the courses are lectures followed by group discussions, while the teaching methods used least often are practical exercises and workshops. This finding was supported by the study of Abu Almaati (2005) that identified a number of problems that have negatively influenced social work education in Egypt, such as the use of old methods of teaching that rely solely on lecturing.

On the other hand, the results showed that although there is a correlation between the degree of success of students and the methods of students' assessment in courses, this correlation is not statistically significant. This means that there is a degree of agreement between students with a high degree of success and students with a low or middle degree of success within the assessment methods used. This indicates a degree of satisfaction among students at different levels with the assessment methods used, including their diversity and ability to measure the intended learning outcomes for these courses. This may be in line with the findings indicated by the degree of diversity in the methods of assessment used and the questions contained in these methods.

Finally, the results of the study showed that there were no statistically significant differences between the students' gender (male-female) on the questionnaire used and its dimensions (the intended learning outcomes - the methods of students' assessment). This indicates that there is no effect on the responses of the students (male and female) used in the study.

In light of the findings of the study and its discussion, many positives were found, as well as some shortcomings. Therefore, it was necessary to develop a set of proposals that raise the standard of courses in the field of social work with individuals and families by dealing with the shortcomings shown by the results of this study, as follows:

1) Review the contents of the courses to help achieve the intended learning outcomes. 
2) Diversify the teaching methods of these courses so that they are not limited to lectures and group discussions only, but include teaching methods that focus on practical and professional applications such as case analysis and workshops that help students to cooperate, think collectively, and discuss.

3) Give greater attention and focus to professional and practical skills in these courses, especially in courses undertaken during the last academic year before students graduate.

4) The assessment process should give greater attention to questions that test students' practical skills, especially in courses of a practical nature such as the course of practice processes with individuals and families.

\section{References:}

Abu Almaati, M. (2005) Quality of Social Work Education and Practice: Between Reality and Expectation of Modernization. Paper presented at the 18th Annual Social Work Conference, Helwan University, Helwan, Egypt.

Anderson, L.W., \& Krathwohl (Eds.). (2001). a Taxonomy for Learning, Teaching, and Assessing: A Revision of Bloom's Taxonomy of Educational Objectives. New York: Longman.

Biggs, J \& Tang C, (2007). Teaching for quality learning at university. Open University Press/Society for Research into Higher Education. $3^{\text {rd }} \mathrm{Ed}$.

Dhemba, J. (2012) Fieldwork in Social Work Education and Training: Issues and Challenges in the Case of Eastern and Southern Africa, Social Work \& Society, international Online Journal Volume 10(1) p.p 1-16.

Kennedy, D. (2007). Writing and Using Learning Outcomes: A Practical Guide, Belfast, Quality Promotion Unit, UCC.

Garthwait, C. L. (2014). The social work practicum a guide and workbook for students (6th Ed.). Boston, MA: Pearson Education.

International Assembly for Collegiate Business Education (IACBE) (2016) Bloom's Taxonomy of Educational Objectives and Writing Intended Learning Outcomes Statements, Lenexa, Kansas

Jarkko, H. et al (2002). Assessing Learning-to-Learn A Framework, Centre for Educational Assessment, Helsinki University, in collaboration with the National Board of Education in Finland Helsinki, Finland.

Kasem, M. (2006). "Social worker skills in problem solving with students at schools" paper presented at the 18th Annual Social Work Conference, Helwan University, Helwan, Egypt, 12-13 March, p.p 261-321.

Learning and Teaching Center (2009) Writing learning outcomes, Macquarie University. 
Mokhtar, A. (2006) 'Indicators for Quality Social Work Education', paper presented at the 19th Annual Social Work Conference, Helwan University, Egypt.

National Authority for Quality Assurance and Accreditation of Education (NAQAAE) (2015) Accreditation Handbook of Higher Education Institutions in Egypt. No.3.

Office of Planning and Assessment (2008). Writing and Assessing CourseLevel

Student Learning Outcomes, Texas Tech University, retrieved from, https://www.depts.ttu.edu/opa/resources/docs/Writing_Learning_Outcomes_ Hook3.pdf.

Soliman H. \& Abdelmaguid H. (2010). The challenges of modernization of social work education in developing countries: The case of Egypt, International Social Work 53(1) 101-114.

The national quality assurance and accreditation committee in collaborative with British Consultation in Higher Education (NAQAAE) (2007). The Quality Assurance and Accreditation Handbook For Higher Education in Egypt, $2^{\text {nd }}$ Ed.

Thomas, K (2004). Learning Taxonomies in the Cognitive, Affective, and Psychomotor Domains, Rocky Mountain Alchemy. Retrieved from http://www.rockymountainalchemy.com/whitePapers/rma-wp-learningtaxonomies.

Williamson, M. (2013) Good practice guide on writing aims and learning outcomes, The Learning Institute at Queen Mary, University of London. 